\title{
ARTICULAR EMINENCE INCLINATION IN MEDIEVAL AND CONTEMPORARY CROATIAN POPULATION
}

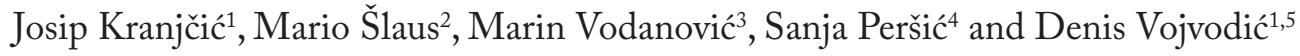 \\ ${ }^{1}$ Department of Fixed Prosthodontics, School of Dental Medicine, University of Zagreb; \\ ${ }^{2}$ Croatian Academy of Sciences and Arts; ${ }^{3}$ Department of Anthropology, ${ }^{4}$ Department of Removable \\ Prosthodontics, School of Dental Medicine, University of Zagreb; \\ ${ }^{5}$ Department of Prosthodontics, Dubrava University Hospital, Zagreb, Croatia
}

\begin{abstract}
SUMMARY - Articular eminence inclination (AEI) of the temporomandibular joint leads the mandible in its movements. Therefore, the aim of the present study was to determine AEI values in medieval (MP) and recent (RP) Croatian population. The study was carried out on two groups of specimens: first group with $30 \mathrm{MP}$ human dry skulls, while the other, serving as control group consisted of 137 dry skulls. The AEI was measured on lateral digital skull images as the angle between the best fit line drawn along the posterior wall of the articular eminence and the Frankfurt horizontal plane. No statistically significant ( $p>0.05$ ) differences between the left and right side AEI were found between MP skulls and RP skulls. The mean value of MP AEI was $45.5^{\circ}$, with a range of $20.9^{\circ}-64^{\circ}$. The mean RP AEI value was steeper $\left(61.99^{\circ}\right)$, with a range of $30^{\circ}-94^{\circ}$. Difference between the mean MP and RP AEI values was statistically significant $(p<0.05)$. Values of AEI vary a lot. Nonsignificant differences between the left and right side AEI confirmed the natural left-right side asymmetry. The values of AEI differ between the RP and MP groups, most probably due to different type of food consumption in medieval time, and consequently different masticatory loads and forces.
\end{abstract}

Key words: Temporomandibular joint - anatomy and histology; Skull - anatomy and histology; Articular eminence; Croatia; Humans

\section{Introduction}

The nature of human masticatory system (development, morphology and physiology) is very complex. Masticatory system includes organs and structures which are primarily functioning in mastication ${ }^{1,2}$. Mastication, the action of breaking down of food, preparatory to deglutition, is one of the most important functions of the masticatory system ${ }^{2}$, thereby multiple muscle groups interact and produce forces ${ }^{3}$. Mechanical loading (masticatory forces) is transferred onto the osseous components of the system, and, at least in part, through the temporomandibular joints to the cranial

Correspondence to: Josip Kranjčic, DMD, School of Dental Medicine, University of Zagreb, Department of Prosthodontics, Dubrava University Hospital, Av. G. Šuška 6, HR-10000 Zagreb, Croatia E-mail: kranjcic@sfzg.hr

Received May 25, 2015, accepted September 4, 2015 base, consequently affecting the process of bone remodeling.

Human temporomandibular joint is an integrative component of the masticatory apparatus, one of the most complex joints in the human body, and is still the subject of extensive investigations and controversy $y^{4,5}$. The temporomandibular articular surfaces are highly incongruent, which means that the upper and lower surfaces are different in shape and size. This incongruence is passed by cartilaginous articular disc which is able to move together with mandibular condyle along the articular eminence. Considering its morphology, temporomandibular joint allows a large range of mandibular movements and consequently transmission of forces and loads on the skull base ${ }^{6,7}$. The articular eminence is therefore made up of thick and dense bone, which is suitable for loadbearing ${ }^{8}$. 
Skeletal structures of the temporomandibular joint undergo remodeling throughout the life ${ }^{9}$. The morphology of the articular eminence, glenoid fossa and mandibular condyle depends on numerous factors, such as changes in dentition associated with aging (tooth loss, attrition and/or increased function), degenerative changes of the glenoid fossa, masticatory stress, craniofacial growth, gender, ethnicity and the relationship between the fossa and the eminence in relation to the facial structures ${ }^{4,6,10-13}$. Its functional morphology also depends on the morphological changes of the cranial base during ontogeny and hominid evolution, and mechanical properties of the craniofacial skeleton (environmental factors, food consistency and toughness $)^{4}$. In a primate model, the temporomandibular joint is loaded during different types of activities such as drinking, screaming, biting and mastication ${ }^{14}$. An important element in the biomechanics of temporomandibular joint and the entire masticatory system is the posterior wall of the articular eminence. The slope (flatness or steepness) of the posterior wall of the articular eminence and its inclination determine the condylar path, which leads the mandible in its movements ${ }^{7,11}$. Articular eminence inclination (AEI) is defined as an angle formed by the posterior wall of the articular eminence and some horizontal plane, e.g., Frankfurt horizontal plane ${ }^{11}$. At birth, the articular eminence is completely flat, which means that the articular eminence in humans is developed almost entirely postnatally as the result of function. The AEI appears to increase with age $\mathrm{e}^{7,11,15,16}$, and full inclination is reached by the age of 30 years ${ }^{11}$.

Interpretation of archaeological material is an important step in the attempt to reconstruct past lives. These data could help in understanding what people ate and how they lived ${ }^{17}$. Little is known about AEI values in medieval population. There is a difference in feeding behavior and the type of diet consumed in medieval and in modern time. Consequently different biomechanical forces (masticatory forces) affect teeth, jawbones, temporomandibular joints, as well as the AEI, and the entire craniofacial system. In the medieval period, the Croatian population (especially in east Croatia) was mostly agricultural, and the food was more soft with much soluble material ${ }^{17,18}$. It is assumed that chewing such a food required lower masticatory forces and wide lateral mandibular movements. Therefore, specific hypothesis was established: there is a dif- ference in AEI between medieval and recent human population. The aim of the present study was to determine the values of AEI in medieval population (MP), and to compare the measured values with the values in recent population $(\mathrm{RP})$.

\section{Materials and Methods}

Two groups of human dry skulls were included in this study, with a total number of 167 specimens. The first group consisted of 30 dry skulls stored in the Anthropological Center, Croatian Academy of Sciences and Arts in Zagreb, Croatia. These skulls are part of a bigger sample which was not fully suitable for use in this study due to different levels of damage. The skulls were excavated at the end of the $19^{\text {th }}$ century and the beginning of the $20^{\text {th }}$ century from four early medieval cemeteries $\left(10^{\text {th }}-11^{\text {th }}\right.$ centuries) in Croatia. In this group of skull specimens, age range was known (30-55 years), but gender was not determined. The other investigated group consisted of 137 dry skull specimens (which served as a control group) taken from the osteologic collection $\left(20^{\text {th }}\right.$ century) of the Institute of Anatomy, School of Medicine, University of Zagreb. This group of specimens had complete data on age and gender. There were 93 male specimens and 44 female specimens from 18 to 88 years of age. All selected specimens from both groups were without damage in the measured area (articular eminence, articular fossa, acoustic external meatus and orbitae).

Skulls were photographed (lateral view) from a distance of 35 centimeters using Olympus C-770 camera (Olympus, Tokyo, Japan), which was placed on a table camera holder (Hama, Mannheim, Germany). All the skulls were placed on a flat camera holder surface and lined on the underside with condensation silicone impression material (Optosil, Heraeus, Hanau, Germany) to obtain a symmetric orientation of the sagittal plane parallel to the surface of the table camera holder (perpendicular to the camera lens). Photographs with lateral views of both sides of the skulls were taken for each specimen to perform measurement of the $\mathrm{AEI}^{19}$. The measurements were performed on digital images using the software application VistaMetrix (Skillcrest LLC, Tucson, Arizona, USA). The AEI was measured in relation to the Frankfurt horizontal plane. Two points, Porion and Orbitale, were marked on the digital images. Porion is the highest point of the acoustic 


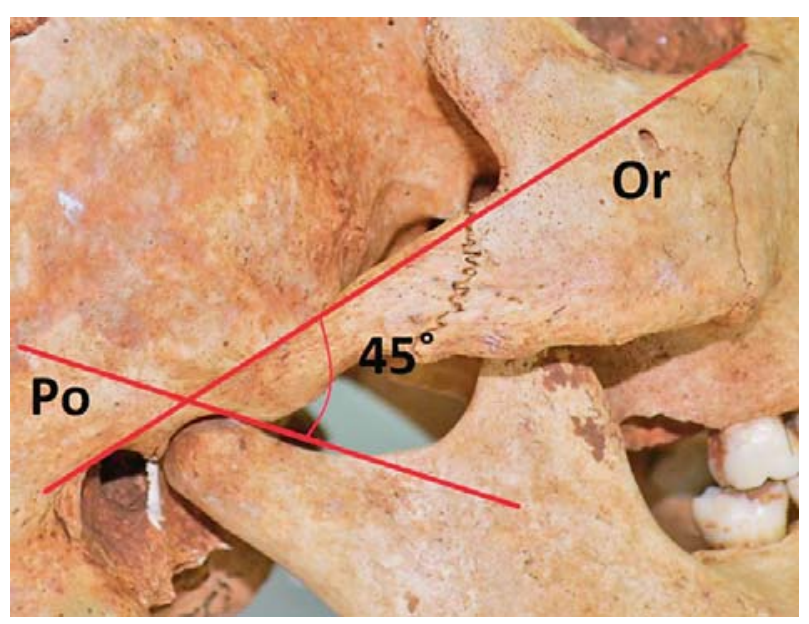

Fig. 1. Articular eminence inclination measured in relation to the Frankfurt horizontal plane (Po, porion; Or, orbitale).

external meatus and Orbitale is the most inferior-anterior point of the orbital rim. The Frankfurt horizontal is defined as a line connecting the Orbitale and Porion points ${ }^{20,21}$. The AEI (Fig. 1) was then defined as the angle between the best fit line drawn along the posterior wall of the articular eminence and the Frankfurt horizontal plane ${ }^{19}$. Using the VistaMetrix software, the values of the angles were measured and expressed in degrees. The results were statistically analyzed using the SPSS 15.0 (SPSS Inc., Chicago, Illinois, USA) software by the method of descriptive statistics, and differences between arithmetic means were tested for significance by the independent-sample Student's T-test.

\section{Results}

The MP skull specimens were aged 30-55 years, mean age $42.5 \pm 6.02$ years. The RP skull specimens were aged $18-88$ years, mean age $45.7 \pm 7.30$ years. Considering gender distribution, the RP human dry skulls included 93 (67.9\%) male and 44 (32.1\%) female specimens.

The mean value of the left AEI measured in MP specimens was $45.75^{\circ}$, while the mean right MP AEI value was slightly and nonsignificantly lower, $45.1^{\circ}$ ( $p>0.05$ ). The mean value of AEI measured in all MP specimens was $45.5^{\circ}$, with the range of $20.9^{\circ}-64^{\circ}$ (Table 1).

The mean measured value of the left AEI in RP specimens was $61.77^{\circ}$, while the right side AEI was slightly and nonsignificantly higher, $62.2^{\circ}(\mathrm{p}>0.05)$. The mean AEI value of all the RP specimens was $61.99^{\circ}$, with the range of $30^{\circ}-94^{\circ}$ (Table 1 ).

Since the difference between the left and right AEI values in both MP and RP groups of specimens was small and not statistically significant $(p>0.05)$, all the measured left and right side values were categorized into two larger groups (all MP and all RP specimens).

When the left side AEI values of $\mathrm{MP}\left(45.75^{\circ}\right)$ and $\mathrm{RP}\left(61.77^{\circ}\right)$ specimens were compared, the difference was statistically significant $(\mathrm{p}<0.05)$. Statistically significant difference was also found on the right side AEI between MP (45.1 ) and RP (62.2 ) samples $(\mathrm{p}<0.05)$. Comparison of the mean value of all MP $\left(45.5^{\circ}\right)$ and all RP $\left(61.99^{\circ}\right)$ specimens also yielded a statistically significant difference $(\mathrm{p}<0.05)$.

\section{Discussion}

Due to the complexities in morphology and movements determined by its morphology, the human temporomandibular joint is often a focal point for investigation and discussion ${ }^{22}$. Richards ${ }^{5}$ has stated that the morphology of temporomandibular joint is related to the morphology of the system with which the joint is

Table 1. Values and statistical parameters of articular eminence inclination in the medieval (MP) and recent (RP) specimens

\begin{tabular}{|c|c|c|c|c|c|c|c|c|c|c|c|c|}
\hline \multirow{2}{*}{$\begin{array}{l}\text { Articular } \\
\text { eminence } \\
\text { inclination }\end{array}$} & \multicolumn{5}{|c|}{ Medieval (MP) } & \multicolumn{5}{|c|}{ Recent (RP) } & \multirow[b]{2}{*}{$\mathrm{t}$} & \multirow[b]{2}{*}{$\mathrm{p}$} \\
\hline & Min-max & Mean & SD & $\begin{array}{c}\mathrm{t} \\
(\mathrm{L}: \mathrm{R})\end{array}$ & $\mathrm{p}$ & Mir & Mean & $\mathrm{SD}$ & $\begin{array}{c}\mathrm{t} \\
(\mathrm{L}: \mathrm{R})\end{array}$ & $\mathrm{p}$ & & \\
\hline Left (L) & $20.9^{\circ}-59.0^{\circ}$ & $45.75^{\circ}$ & 10.7 & 0237 & $>005$ & $30.0^{\circ}-94.0^{\circ}$ & $61.77^{\circ}$ & 12.21 & 0285 & $>005$ & 6.653 & $<0.05$ \\
\hline Right (R) & $21.6^{\circ}-64.0^{\circ}$ & $45.1^{\circ}$ & 10.6 & 0.201 & 30.05 & $31.0^{\circ}-88.0^{\circ}$ & $62.2^{\circ}$ & 12.34 & 0.283 & $>0.05$ & 7.042 & $<0.05$ \\
\hline All & $20.9^{\circ}-64.0^{\circ}$ & $45.5^{\circ}$ & 10.7 & & & $30.0^{\circ}-94.0^{\circ}$ & $61.99^{\circ}$ & 12.21 & & & 9.74 & $<0.05$ \\
\hline
\end{tabular}

Min $=$ minimal value $\max =$ maximal value $p=p$ value $t \mathrm{t}=\mathrm{t}$ value $\mathrm{SD}=$ standard deviation 
functionally linked. Environmental and orofunctional factors such as mechanical loading may influence the growth and development of skeletal components of the temporomandibular joint. Although the influence of genetic factors cannot be excluded, differences in the nature or intensity of tooth use, tooth attrition or tooth loss, type of consumed food during growth and throughout life related to different levels of orofunctional stress may account, at least in part, for differences in joint size ${ }^{22}$. It can be assumed that all the factors that affect the temporomandibular joints also affect the articular eminence and its inclination. AEI as an important element in the biomechanics of temporomandibular joint was studied by using different materials and methods, and therefore highly variable values were obtained ${ }^{5-7,9}$. For example, the path of movement of the condyle during protrusion corresponds to the contour and height of the eminence. However, with this method, the value of the height and angle of the eminence may be indefinite because of the presence of the incongruous disk ${ }^{6}$. Other methods can also have their own limitations, e.g., measurements on models taken from an impression of the fossa or direct measurement carried out on dry skulls, measurements performed on arthrograms, panoramic radiographs, tomographic radiographs, cephalometric radiographs, scaled photographs, etc. ${ }^{6,15}$. The measurements are difficult due to the complicated structure of the articular eminence and glenoid fossa which consists of many small and complex curved surfaces. Usually two different methods are used for AEI measurements ${ }^{15,19}$. One method is to measure the angle between the best fit line on the slope of the eminence and the Frankfurt horizontal plane, while the other method is to measure the angle between the Frankfurt horizontal plane and the line connecting the roof of the fossa with the highest point of articular eminence. Although both angles represent the AEI, the first angle (best fit line-Frankfurt horizontal) focuses primarily on the posterior surface of the eminence, whereas the other angle (fossa roof-eminence top, Frankfurt horizontal) focuses on the location of the eminence crest relative to the fossa roof $^{15}$. The former method (best fist line-Frankfurt horizontal) was used in the present study because the posterior slope of the articular eminence is easy to observe (and measure the inclination), and represents the actual but simplified condylar path ${ }^{19}$.
According to the results, there was a wide range between minimal and maximal measured values, ranging from $30^{\circ}$ to $94^{\circ}$ among recent specimens and from $20.9^{\circ}$ to $64^{\circ}$ among medieval specimens. Gilboa et al. report that the AEI values usually vary from 21 to 64 degrees ${ }^{21}$. Koyoumdjisky ${ }^{23}$ measured the inclination of the anterior wall of the fossa and obtained a mean value of $47.6^{\circ}$, while Zoghby et al. ${ }^{24}$ found a mean value of $47.46^{\circ}$ using the method of mechanical axiography in study participants. It has been reported that the normal value of AEI in adults is from $30^{\circ}$ to $60^{\circ}$. AEI values smaller than $30^{\circ}$ have been characterized as flat, while those greater than $60^{\circ}$ have been characterized as steep $^{15}$. The results of various studies correspond to this range and are similar to the values recorded in our study ${ }^{21,23-27}$.

In both the medieval and recent sample groups, differences were found between the right and left joints. Jasinevicius et al. ${ }^{7}$ report steeper right AEI values. This finding corresponds to the AEI values recorded in RP specimens in the present study. Conversely, in a group of MP specimens, the right side values were slightly lower than the left side values. The differences observed could probably be caused by the predominant masticatory usage of one jaw side, and a consequently different distribution of the biomechanical loading in the right and left temporomandibular joints. During mastication, transportation of food from one side to the other is necessary, but the one side preference is a well-known and relatively consistent phenomenon ${ }^{4,28}$.

The difference observed in AEI between medieval $\left(45.5^{\circ}\right)$ and recent $\left(61.99^{\circ}\right)$ specimens was statistically significant. Therefore, the results obtained confirmed the assumed hypothesis about difference in AEI values between MP and RP human populations. Both skull populations were ethnically homogeneous. Difference between the two populations was in their lifestyle and type of food consumed. The early medieval MP population was intensely agricultural with a high consumption of cereals, a food that was not so hard and contained much soluble materia ${ }^{19}$. As a result, lower masticatory forces were needed for food processing. In such conditions, remodeling of joint components was less pronounced. If the food is harder and tougher (e.g., meat), stronger masticatory forces are needed for chewing, which is more typical for recent population. Glenoid fossa appears to undergo remodeling in re- 
sponse to the patterns of forces generated during the mastication function ${ }^{29}$, and with stronger forces, the fossa becomes deeper, whereas the AEI becomes steeper. The anatomy of the temporomandibular joint exerts an important influence on the magnitude of the lower jaw movements; ${ }^{7}$ therefore less pronounced articular eminence with a lower AEI allows greater freedom of movements ${ }^{19}$. According to this, a wider range of lateral mandibular movements with lower masticatory forces was typical in processing the 'medieval' diet.

The AEI values can vary a lot. The range of values is wide and it differs inter-individually. Environmental factors related to the type of diet and masticatory forces may affect the joint morphology and AEI, therefore lower masticatory forces are connected with shallower fossa and lower inclination. However, owing to the method of measurement employed and variability of the results, the values obtained could be used as orientational information that may prove helpful in setting articulators with the mean values of condylar path inclination, while further measurements (investigations) are needed to support these findings.

\section{References}

1. Koolstra JH. Dynamics of the human masticatory system. Crit Rev Oral Biol Med. 2002;13(4):366-76. doi: 10.1177/154411 130201300406

2. Soboleva U, Laurina L, Slaidina A. The masticatory system an overview. Stomatologija. 2005;7(3):77-80.

3. Curtis N. Craniofacial biomechanics: an overview of recent multibody modelling studies. J Anat. 2011;218(1):16-25. doi: 10.1111/j.1469-7580.2010.01317.x.

4. Koppe T, Schöbel SL, Bärenklau M, Bruchhaus H, Jankauskas $\mathrm{R}$, Kaduk WMH. Factors affecting the variation in the adult temporomandibular joint of archaeological human populations. Ann Anat. 2007;189(4):320-5. doi:10.1016/j.aanat.2007.02.018

5. Richards LC. Temporomandibular joint morphology in two Australian aboriginal populations. J Dent Res. 1987;66(10): 1602-7. doi: 10.1177/00220345870660101901

6. Ikai A, Sugisaki M, Young-Sung K, Tanabe H. Morphologic study of the mandibular fossa and the eminence of the temporomandibular joint in relation to the facial structures. Am J Orthod Dentofac Orthop. 1997;112(6):634-8.

7. Žabarović D, Jerolimov V, Carek V, Vojvodić D, Žabarović K, Buković D. The effect of tooth loss on the TM-joint articular eminence inclination. Coll Antropol. 2000;24 Suppl 1:S37-42.

8. Okeson JP. Management of temporomandibular disorders and occlusion. $5^{\text {th }}$ ed. St. Louis: Mosby; 2003.
9. Meng F, Liu Y, Hu K, Zhao Y, Kong L, Zhou S. A comparative study of the skeletal morphology of the temporo-mandibular joint of children and adults. J Postgrad Med. 2008;54(3):191-4

10. Jasinevicius TR, Pyle MA, Nelson S, Lalumandier JA, Kohrs KJ, Sawyer DR. Relationship of degenerative changes of the temporomandibular joint (TMJ) with the angle of eminentia.J Oral Rehabil. 2006;33(9):638-45.

11. Reicheneder C, Gedrange T, Baumert U, Faltermeier A, Proff P. Variations in the inclination of the condylar path in children and adults. Angle Orthod. 2009;79(5):958-63. doi: 10.2319/08 1108-425.1.

12. Wu CK, Hsu JT, Shen YW, Chen JH, Shen WC, Fuh LJ. Assessments of inclinations of the mandibular fossa by computed tomography in an Asian population. Clin Oral Invest. 2012; 16(2):443-50. doi: 10.1007/s00784-011-0518-y

13. Badel T, Ćimić S, Munitić M, Zadravec D, Bašić Kes V, Kraljević Šimunković S. Clinical view of the temporomandibular joint disorder. Acta Clin Croat. 2014;53(4):462-70.

14. Tuijt M, Koolstra JH, Lobbezoo F, Naeije M. Difference in loading of the temporomandibular joint during opening and closing of the jaw. J Biomech. 2010;43(6):1048-54. doi: 10.1016/j.jbiomech.2009.12.013

15. Katsavrias EG. The effect of mandibular protrusive (activator) appliances on articular eminence morphology. Angle Orthod. 2003;73(6):647-53. doi: 10.1043/0003-3219(2003)073<0647: TEOMPA>2.0.CO;2

16. Nickel JC, McLachlan KR, Smith DM. Eminence development of the postnatal human temporomandibular joint. J Dent Res. 1988;67(6):892-902.

17. Vodanović M, Brkić H, Šlaus M, Demo Z. The frequency and distribution of caries in the mediaeval population of Bijelo Brdo in Croatia $\left(10^{\text {th }}-11^{\text {th }}\right.$ century). Arch Oral Biol. 2005; 50(7):669-80. doi: 10.1016/j.archoralbio.2004.11.014

18. Vodanović M, Brkić H, Demo Z, Šlaus M. Dental disease and dietary pattern in the early medieval population from Bijelo Brdo - East Slavonia, Croatia. Acta Stomatol Croat. 2003; 37(4):386-7.

19. Kranjčić J, Vojvodić D, Žabarović D, Vodanović M, Komar D, Mehulić K. Differences in articular-eminence inclination between medieval and contemporary human populations. Arch Oral Biol. 2012;57(8):1147-52. doi: 10.1016/j.archoralbio. 2012.05.009

20. Seifert D, Jerolimov V, Carek V. Terminal hinge axis-hobo point-Frankfurt horizontal relations. Coll Antropol. 2000;24 (2):479-84.

21. Gilboa I, Cardash HS, Kaffe I, Gross MD. Condylar guidance: correlation between articular morphology and panoramic radiographic images in dry human skulls. J Prosthet Dent. 2008;99(6):477-82. doi: 10.1016/S0022-3913(08)60112-2

22. Hinton RJ. Relationships between mandibular joint size and craniofacial size in human groups. Arch Oral Biol. 1983;28 (1):37-43. 
23. Koyoumdjisky E. The correlation of the inclined planes of the articular surface of the glenoid fossa with the cuspal and palatal slopes of the teeth.J Dent Res.1956;35(6):890-901. doi: http:// dx.doi.org/10.1016/0002-9416(56)90131-2

24. Zoghby AE, Re JP, Perez C. Functional harmony between the sagittal condylar path inclination and the anterior guidance inclination. J Stomat Occ Med. 2009;2(3):131-6. doi: 10.1007/ s12548-009-0024-x

25. Angyal J, Szabo J, Pataky L. Mathematical description of the forward movement of the mandibular condyle. Int J CARS. 2009;4:207-212.

26. Baqaien MA, Barra J, Muessig D. Computerized axiographic evaluation of the changes in sagittal condylar path inclination with dental and physical development. Am J Orthod Dentofacial Orthop. 2009;135(1):88-94. doi: 10.1016/j.ajodo.2007.01.030

27. Matsumura H, Tsukiyama Y, Koyano K. Analysis of sagittal condylar path inclination in consideration of Fischer's angle. J Oral Rehabil. 2006;33(7):514-9. doi: 10.1111/j.1365-2842. 2006.01590.x

28. Wilding RJ, Adams LP, Lewin A. Absence of association between a preferred chewing side and its area of functional occlusal contact in the human dentition. Arch Oral Biol. 1992; 37(5):423-8.

29. Owen CP, Wilding RJC, Adams LP. Dimensions of the temporal glenoid fossa and tooth wear in prehistoric human skeletons. Arch Oral Biol. 1992;37(1):63-7.

Sažetak

\section{NAGIB STRAŽNJEGA ZIDA ZGLOBNE KVRŽICE SREDNJOVJEKOVNE I SUVREMENE HRVATSKE POPULACIJE}

\section{J. Kranjčić, M. Šlaus, M. Vodanović, S. Peršić i D. Vojvodić}

Kretnje donje čeljusti određene su nagibom stražnjega zida zglobne kvržice (engl. articular eminence inclination, AEI) temporomandibularnog zgloba. Svrha istraživanja je bila odrediti vrijednosti AEI na uzorku iz srednjovjekovne (engl. medieval population, MP) i moderne (engl. recent population, RP) hrvatske populacije. Istraživanje je provedeno na dvije skupine uzoraka: $30 \mathrm{MP}$ lubanja i druga skupina sa 137 lubanja kao kontrolna skupina. AEI je mjeren na lateralnim digitalnim fotografijama lubanja kao kut što ga čini najbolje prilagođena linija strmini stražnjega zida zglobne kvržice s frankfurtskom ravninom. Nije bilo statistički značajnih razlika $(p>0,05)$ između vrijednosti AEI lijeve i desne strane u uzorku MP i RP. Srednja izmjerena MP vrijednost AEI bila je 45, $5^{\circ}$ u rasponu vrijednosti od 20,9 $9^{\circ}$ do $64^{\circ}$. Srednja izmjerena RP vrijednost AEI bila je viša, $61,99^{\circ}$, s rasponom vrijednosti od $30^{\circ}$ do $94^{\circ}$. Razlika srednjih vrijednosti AEI između skupina MP i RP bila je statistički značajna $(p<0,05)$. Vrijednosti AEI su vrlo varijabilne. Razlika (statistički neznačajna) između vrijednosti AEI lijeve i desne strane upućuje na prirodnu asimetriju. Razlike u vrijednostima AEI između skupina RP i MP postoje vjerojatno zbog različite prehrane u srednjem vijeku te posljedično tome različitim žvačnim silama i opterećenju.

Ključne riječi: Temporomandibularni zglob - anatomija i histologija; Lubanja - anatomija i histologija; Zglobna izbočina; Hrvatska; Ljudi 